\title{
Creating Engaging Experiences in MOOCs through In- Course Redeemable Rewards
}

Citation for published version (APA):

Ortega-Arranz, A., Kalz, M., \& Martínez-Monés, A. (2018). Creating Engaging Experiences in MOOCs through In-Course Redeemable Rewards. In 2018 IEEE Global Engineering Education Conference (EDUCON 2018): Proceedings of a meeting held 17-20 April 2018, Santa Cruz de Tenerife, Spain. (pp. 1875-1882). IEEE. https://doi.org/10.1109/EDUCON.2018.8363464

DOI:

10.1109/EDUCON.2018.8363464

Document status and date:

Published: 01/02/2018

Document Version:

Peer reviewed version

Document license:

CC BY-NC-ND

Please check the document version of this publication:

- A submitted manuscript is the version of the article upon submission and before peer-review. There can be important differences between the submitted version and the official published version of record. People interested in the research are advised to contact the author for the final version of the publication, or visit the DOI to the publisher's website.

- The final author version and the galley proof are versions of the publication after peer review.

- The final published version features the final layout of the paper including the volume, issue and page numbers.

Link to publication

\section{General rights}

Copyright and moral rights for the publications made accessible in the public portal are retained by the authors and/or other copyright owners and it is a condition of accessing publications that users recognise and abide by the legal requirements associated with these rights.

- Users may download and print one copy of any publication from the public portal for the purpose of private study or research.

- You may not further distribute the material or use it for any profit-making activity or commercial gain

- You may freely distribute the URL identifying the publication in the public portal.

If the publication is distributed under the terms of Article 25fa of the Dutch Copyright Act, indicated by the "Taverne" license above, please follow below link for the End User Agreement:

https://www.ou.nl/taverne-agreement

Take down policy

If you believe that this document breaches copyright please contact us at:

pure-support@ou.nl

providing details and we will investigate your claim.

Downloaded from https://research.ou.nl/ on date: 26 Apr. 2023 


\section{Creating Engaging Experiences in MOOCs through In-Course Redeemable Rewards}

\author{
Alejandro Ortega-Arranz \\ GSIC-EMIC Research Group \\ Universidad de Valladolid \\ Valladolid, Spain \\ alex@gsic.uva.es
}

\author{
Marco Kalz \\ UNESCO Chair of Open Education, \\ Faculty of Management, Science and \\ Technology \& Welten Institute, \\ Open University of the Netherlands \\ Heerlen, The Netherlands \\ marco.kalz@ou.nl
}

\author{
Alejandra Martínez-Monés \\ GSIC-EMIC Research Group \\ Universidad de Valladolid \\ Valladolid, Spain \\ amartine@infor.uva.es
}

\begin{abstract}
Gamification strategies have been proposed to mitigate student disengagement and dropouts in massive online environments, due to the positive results shown by these strategies at lower scales. Among various gamification strategies, redeemable rewards have been identified as an effective element to intrinsically motivate students and increase their engagement in educational settings, including MOOCs. Yet, effective design, implementation and enactment of this gamification strategy in MOOC contexts might face new challenges, given the unique characteristics of these learning settings such as massiveness. As an attempt to help teachers use redeemable rewards in MOOCs, this paper analyzes the characteristics of MOOCs that influence its integration and presents a proposal of a system supporting the design, implementation and enactment of such rewards. The envisioned system is illustrated by a scenario that describes the main features of this system for teachers and students.
\end{abstract}

Index Terms-Gamification, MOOCs, Engagement, Rewards, Redeem.

\section{INTRODUCTION}

MOOCs are a new form of teaching and learning, with an increasing popularity [21]. MOOCs offer many benefits for students such as learning on-demand, access to education without enrollment fees or involvement in communities around a topic. However, MOOCs are often criticized for their pedagogical quality [14], [20], which leads to low student motivation and engagement, resulting in high dropout rates [1], [12], [13]. Gamification has been proposed to help overcome the previous drawback in MOOCs due to the benefits shown by this strategy in small-scale educational contexts [6], [8].

Gamification is the inclusion of elements and structures that frequently appear in games (e.g., rewards, narrative, engagement loops) into non-game contexts [6], [7]. Although gamification has shown potential to enhance student motivation and engagement, MOOCs have some characteristics (e.g., the large number of students, the heterogeneity of participants, the need for automation when issuing rewards) that can hinder the benefits of gamification already shown in other educational contexts [18], [17]. As a consequence, during the last years there is an increasing number of research studies on the design and implementation of gamification strategies to identify whether such benefits are also applicable to MOOCs [2], [18], [24].
Rewards (e.g., badges, points, virtual goods) are one of the most implemented game elements in gamified educational contexts, including MOOCs [8], [18]. Research in educational psychology has shown that rewards can have positive as well as negative effects depending on the context and reward logic [4]. On the one hand, rewarding strategies allow students to set personal goals, track their progress and promote their reputation and trustworthiness with the rest of course students [11]. On the other hand, rewards which are repeated or do not lead to concrete advantages for learners can have a limited effectiveness or even produce counter-effects. Thus, although rewards have been identified as an engaging game element in MOOC environments [5], their effectiveness strongly depends on the form teachers implement them within the learning environment [9].

Rewards in online-environments and MOOCs are often implemented in the form of digital badges [18]. One of the most influential technology for this purpose was the Mozilla Open Badge infrastructure ${ }^{1}$. The original idea of the open badges project was the recognition of skills shown in nonformal context by employers with a clear focus on transfer of these achievements between different contexts. If badges are provided in MOOCs, the question arises for whom these achievements are relevant and if the transfer to external contexts is possible at all.

To address the problem of potential low effectiveness and to avoid meaningless rewarding strategies in MOOCs, we propose the use of in-course redeemable rewards: rewards (e.g., points, cards, tickets) that are issued to students when completing pre-defined learning-oriented tasks, and which students can exchange to attain various privileges during the course runtime. In many games, rewards can be redeemed or exchanged for unlocking or buying contents and objects (e.g., new figures, weapons, stages). Utilizing rewards in such a way can enhance players' motivation and engagement due to the possibility of achieving such new contents and objects, and using them in the game itself to progress or perform better.

\footnotetext{
${ }^{1}$ Mozilla Foundation (2013). Open Badges. Available at https://openbadges.org, last access: November, 2017.
} 
This concept of redeemable rewards can be applied to MOOCs in order to enhance student motivation and engagement and try to reach students which are not attracted by traditional rewarding strategies (e.g., badges or points as elements of progress and status). To do so, MOOC teachers have to design (e.g., deciding which actions lead to a privilege and where it can be applied), implement (e.g., deploying and configuring the activities and rewards in MOOC platforms) and enact (e.g., issuing and redeeming rewards in run-time) such kind of gamification.

Due to the current limitations of MOOC platforms and gamification tools, teachers have the only possibility of manually implementing and enacting this kind of gamification. However, the massive number of students in these courses and their heterogeneity in the schedule (i.e. there is student activity during the 24h) make the enactment of redeemable rewards not affordable in terms of time investment and effort for the teachers. Therefore, the creation of a system to support teachers in the automation of redeemable rewards in MOOCs could facilitate the implementation of this type of gamification, aiming to enhance the levels of student motivation and engagement.

This paper presents a model and a system proposal to support teachers in the design, implementation and enactment of in-course redeemable rewards in MOOC environments. Students can redeem these rewards during the runtime of the course to get different types of privileges that are expected to have again a positive impact on student learning. The structure of the paper is as follows. The next section introduces previous work on using meaningful rewards in educational contexts. The third section introduces the gamification approach of redeemable rewards in MOOCs. Section 4 presents a system proposal supporting teachers in the design, implementation and enactment of this kind of rewards. Section 5 describes a usage scenario implementing such system. Finally, in the last section some conclusions and future work are outlined.

\section{RELATED WORK}

Previous studies in different educational contexts have proposed and analyzed the effects of implementing rewards that can have an associated privilege for students in the course. Some of the most representative examples are:

Simoes et al. (2013) [22] describe an online educational tool for primary schools (i.e., Schoooools.com) that allows teachers to gamify their teaching processes with different game elements such as rewards (e.g., badges, trophies), feedback indicators and social elements (e.g., "likes"). The authors make explicit that teachers and parents can make use of tangible rewards (e.g., tickets to a show). Tangible rewards are rewards that do not represent course students' status but provide earners with out of course benefits. However, this system is aimed at K-6 small-scale courses where the rewards are manually issued and the privileges are out of the course and non directly related with the student learning. This manual issuing and external use is less transferable to the MOOC environment due to the masses and diversity of participants.
Ding et al. (2017) [10] created a gamified online forum environment for two (online and blended) courses. The environment allows teachers to gamify discussion forums with a set of game elements (e.g., points, badges, levels). Students earn points when completing the tasks pre-defined by teachers. Once students' scores (or points) reach the pre-defined thresholds, students level-up and unlock new features in the system such as "emojis" and "gifts" that can be used in the online discussions. Results show that most of the students achieved the final level. These online and in-course rewards could be suitable for MOOCs. However, they are limited to tasks and privileges in discussion forums omitting other tools frequently used in MOOCs that could boost the gamification effects in other kind of activities.

O'Donovan et al. (2013) [16] presented a positive gamification experience of a university blended-learning course about computer game development. Among the different rewards that the teachers implemented in the course, what authors call steam points can be considered as redeemable rewards. Steam points are issued to students when they collect specific amounts of experience points issued when completing quizzes, attending lectures, participating in class exercises and showing a high level of creativity in the assignments. Students could visit the shop page and spend their steam points for buying new attempts in quizzes, hints for course puzzles, rewards for the whole class and assignment deadline extensions. Although teachers provided a variety of in-course redeemable rewards, the transfer to the MOOC context is limited due to the manual reward procedure and the tailored implementation for one specific course.

Morales et al. (2016) [15], [19] describe the gamification process implemented in a MOOC that teaches the use of authoring tools in e-learning courses. The MOOC was targeted at teachers in higher education. Several game elements were implemented in the course such as badges and leaderboards. Templates for the tools employed during the course were issued as rewards when participants finished the weekly assignments on time. Results in the final questionnaire show that templates were the preferred gamification strategy for the students. In this case, the actions performed in an activity (i.e., weekly assignment) provided a privilege to the students (i.e., templates), to be used in a different activity of the course or even in their own teaching processes. However, templates as rewards are tied to the use of these specific authoring tools.

Different from previous studies, Chang and Wei (2016) [5] conducted an online survey to 5020 MOOC students to determine the engagement level of 40 game elements in MOOC environments. Although some options are not common elements of games (e.g., learning forums, peer mentoring), redeemable points were identified as the second most engaging game element in MOOCs. In this survey, redeemable points refers to accumulated points that students can exchange for real world rewards such as items, toys or game software. Therefore, considering the results of this survey, redeemable points seem to be a good strategy to increase student engagement in MOOCs. However, as explained before, physical 


\begin{tabular}{|c|c|c|c|}
\hline Ref. & Context & Reward & Effects \\
\hline$[22]$ & $\begin{array}{l}\text { Primary } \\
\text { school } \\
\text { courses }\end{array}$ & $\begin{array}{l}\text { Tangible } \\
\text { rewards (e.g., } \\
\text { tickets to a } \\
\text { show) }\end{array}$ & - No real implementation \\
\hline [10] & $\begin{array}{l}\text { An online } \\
\text { graduate } \\
\text { course \& A } \\
\text { undergradu- } \\
\text { ate blended } \\
\text { course }\end{array}$ & $\begin{array}{l}\text { New features } \\
\text { in discussion } \\
\text { forums (e.g., } \\
\text { emojis, gifts) }\end{array}$ & $\begin{array}{l}\text { - Positive impact on } \\
\text { engagement reported by the } \\
\text { students and increase in the } \\
\text { number of discussion posts } \\
\text { - Most students unlocked all } \\
\text { features }\end{array}$ \\
\hline [16] & $\begin{array}{l}\text { A under- } \\
\text { graduate } \\
\text { blended- } \\
\text { learning } \\
\text { course }\end{array}$ & $\begin{array}{l}\text { Extra attemps } \\
\text { in quizzes, } \\
\text { hints for } \\
\text { course } \\
\text { puzzles, } \\
\text { deadline } \\
\text { extensions }\end{array}$ & $\begin{array}{l}\text { - Students felt that the } \\
\text { gamification improved their } \\
\text { understanding and particularly } \\
\text { their engagement } \\
\text { - Steam Points (redeemable for } \\
\text { privileges) was vote as the sec- } \\
\text { ond most motivated element } \\
\text { over progress bars, prizes and } \\
\text { badges }\end{array}$ \\
\hline $\begin{array}{l}{[15],} \\
{[19]}\end{array}$ & A MOOC & $\begin{array}{l}\text { Templates for } \\
\text { the tools } \\
\text { employed } \\
\text { during the } \\
\text { course }\end{array}$ & $\begin{array}{l}\text { - Increase of motivation to } \\
\text { complete the assigned learning } \\
\text { activities } \\
\text { - Templates were the preferred } \\
\text { type of reward voted by stu- } \\
\text { dents }\end{array}$ \\
\hline$[5]$ & MOOCs & $\begin{array}{l}\text { Redeemable } \\
\text { points for } \\
\text { real world } \\
\text { rewards }(e . g . \text {, } \\
\text { toys, game } \\
\text { software) }\end{array}$ & $\begin{array}{l}\text { - A survey to } 5020 \mathrm{MOOC} \\
\text { students pointed redeemable } \\
\text { points as the second most } \\
\text { engaging element in MOOC } \\
\text { environments }\end{array}$ \\
\hline
\end{tabular}

TABLE I

RELATED WORK SUMMARY

rewards are difficult to transfer to MOOC environments. Also, access to games as reward is a very specific rewarding strategy which could have an impact for only a small part of the MOOC population.

This section has presented several learning situations involving rewards with feasible benefits for learners. In general, this kind of reward showed a positive acceptance by students (see Table I). However, the aforementioned rewards are either not applicable in MOOCs (i.e., physical objects, manual rewards), are limited to specific activities (i.e., forum activities), are tied to specific tools and courses (i.e., authoring tools, game development) or are non-content related rewards (i.e., game software). Our gamification proposal tries to make use of the common elements present in most MOOCs to provide instructors with a broad set of course privileges to increase student engagement in any type of MOOC.

\section{REWARDing MOdEL PROPOSAL}

This section introduces a generic conceptual model for Redeemable Rewards (RRs) in MOOCs and its suitability.

\section{A. Suitability of RRs for MOOCs}

Although MOOCs have some features that hinder the implementation of gamification in this kind of courses [18], [17], MOOCs also have some features that allow the integration of redeemable rewards in a meaningful way:

- Teachers cannot draw their attention to each student due to overload and time costs because of the massive scale (i.e., more than 500 students). However, teachers can offer

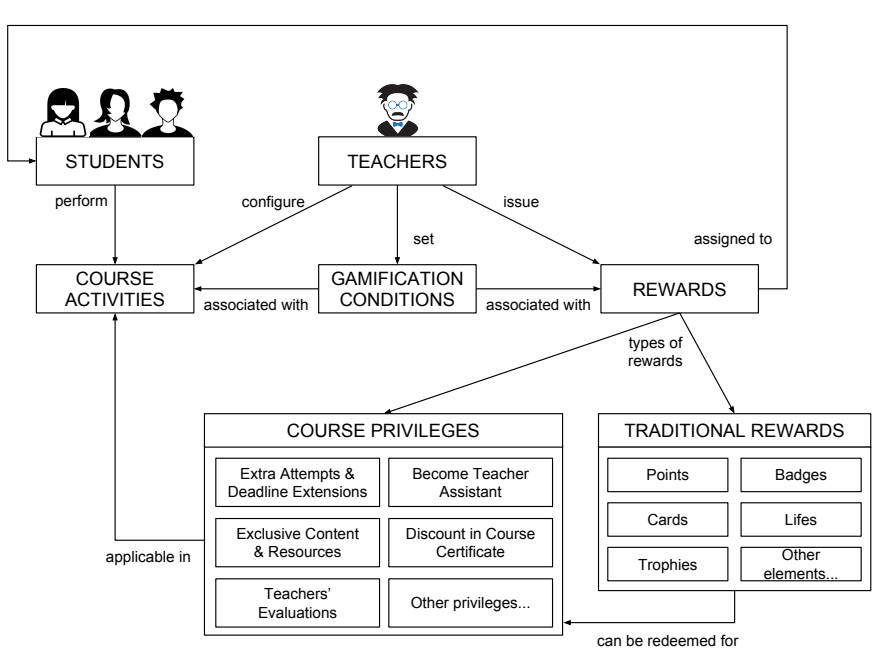

Fig. 1. Proposed RR-based gamification model.

individual attention to a small number of students (e.g., 50 students) as they are used to do in regular online courses by checking their progress and providing feedback to them. Such teacher attention (e.g., special video session with students, teacher evaluation of a submission) can be proposed to those who redeem their rewards. Also, students who show a deep knowledge about the course topic and like to help other students can take the role of teacher assistants and help others in the forums and social networks.

- Teachers are not tied to include specific learning contents, materials and activities as it happens in many official higher education courses. Therefore, MOOCs present a high flexibility in their design, making it possible to offer specific materials and learning activities as rewards, and to allow students to complete the activities in different manners (e.g., in groups, with lower score).

Based on the previous features, in-course redeemable rewards are an attractive approach in terms of gamification in MOOCs.

\section{B. RR-based Gamification Model for MOOCs}

In a traditional reward-based gamification (see Fig. 1), teachers configure course activities, and set gamification conditions under which the rewards will be issued to the students. Commonly, this kind of rewards (traditional rewards) are points, badges, trophies, etc. We have considered a new type of reward (course privileges) which could be directly issued to students after fulfilling the gamification conditions or after redeeming a preconfigured amount of traditional rewards. Furthermore, these course privileges and their gamification conditions are expected to have a positive impact on the learning process of participants.

Thus, we define the concept of in-course redeemable rewards as rewards (e.g., points, cards, tickets) that are issued to students when completing pre-defined learning-oriented tasks, and which students can exchange to attain various privileges during the course runtime. Therefore, students can increase 
their motivation and engagement within the course by trying to reach such privileges. In this way, teachers can also reach out to a higher variety of students present in MOOCs (i.e., different student profiles [1], [23]) by providing different types of privileges, as game-design practitioners recommend [3], [25]. For example, some of these privileges are:

a. accessing exclusive videos and submissions, targeting students enrolled in the course because they have a high interest in the topic.

b. unlocking extra or exclusive learning content and resources, targeting students enrolled in the course to get additional learning material.

c. providing students with extra attempts and/or more time to perform the quizzes, targeting students that want to reach higher scores in the course.

d. extending the due date of the assignments, targeting students that are interested in the course and want to complete it but need more time for performing the assignments.

e. skipping compulsory assignments or passing them with lower scores, targeting students enrolled in the course to obtain the final certificate.

f. allowing students to choose to complete the assignments individually or collectively, targeting students who prefer to work alone, with friends or with new people.

g. accessing exclusive evaluations or assessments performed by the teachers, targeting students who complain about the form and quality of reviews in MOOCs.

h. unlocking new features in forums such as votes, emojis or gifts, targeting students that like to express their opinions, doubts and/or comments through the course forums.

i. serving as teacher assistant of the course, targeting students who like to help other students.

j. receiving the final certificate without fee, targeting students who want to get the course certificate.

This gamification approach would allow students to target the rewards they like from a broad set of possibilities with a focus on strategies that foster again their involvement in learning in the course. Also, students who dislike gamification strategies are free to not get involved or redeem such rewards, allowing them to complete the course without being bothered by the gamification design.

In-course redeemable rewards could be manually implemented and enacted (e.g., teachers could manually check which students got $100 \%$ correct answers in the quizzes and unlock a module with extra content for them). However, the scale of MOOCs makes the manual implementation of this kind of rewards unfeasible, as it would require teachers to manually check which students achieved the goals, and activate the associated redeem for them. Moreover, teachers need help to decide which actions can be redeemable, which rewards are possible in each course design (i.e., based on the implemented tools), create the relationships between activities and rewards based on their pedagogical intentions, etc. Therefore, the creation of a system supporting MOOC teachers in the design, implementation and enactment of this kind of rewards could provide students with run-time feedback and significantly reduce time and cognitive costs for teachers during course design and management.

\section{IN-COURSE REWARDING SySTEM}

Aiming to support teachers in the digital design, implementation and enactment of in-course redeemable rewards, it is needed that gamification designs can be computationally represented. This requires the definition of a data model involving the gamification concepts mentioned in the previous section: (i) course activities (e.g., forum tool, wiki), (ii) monitorable actions performed by the students (e.g., post in a forum, submit a quiz), (iii) conditions that the students have to fulfill (e.g., do the action 3 times, get an score upper than 90\%), (iv) game elements to use (e.g., experience points, tickets), and (v) in-course privileges (e.g., unlock special content, deadline extensions). A system integrating this data model and implementing a graphical interface could help teachers to create and understand digital gamification designs involving in-course rewards. Therefore, the relationships between the activities and the rewards would be clearer than directly configuring them in the course platforms, allowing teachers to better align the gamification design with their pedagogical intentions.

We propose this system as part of an architecture to automatically deploy and enact the gamified designs into MOOC platforms ${ }^{2}$.

The design and deployment system (see Fig. 2) allows teachers to create gamifications involving redeemable rewards (i.e., store the designs in a data base) and deploy them in well-known MOOC platforms (i.e., embed a web page in the MOOC platform showing the configured rewards, their descriptions and buttons to claim the course privileges and/or redeem the traditional rewards). Thanks to the LTI standard ${ }^{3}$, from the MOOC platforms students can seamlessly access to the external gamification web system without additional logins. Therefore, the students request for claiming and redeeming the rewards will be processed by the Gamification enactment systems.

This system will receive such requests during course runtime, checks if the student was previously rewarded (student gamification info), checks whether the students' actions fulfill the gamified design conditions for the course (stored designs $\&$ deploys) by querying to the MOOC platform database (e.g., through the API), and issues and redeems rewards to students if such conditions are fulfilled (connecting again with the MOOC platform database). This system will also integrate the aforementioned gamification data model to understand the gamification designs configured by teachers with the Gamification design and deployment system. The following section illustrates these ideas with a scenario of use of the envisioned system.

\footnotetext{
${ }^{2}$ The adapter-based architecture aims to deploy and enact such gamification designs in different MOOC platforms. This feature is not addressed in this paper (see Fig. 2).

${ }^{3}$ IMS Global. Learning Tools Interoperability (LTI). Available at http://www.imsglobal.org/activity/learning-tools-interoperability, last access: November, 2017.
} 


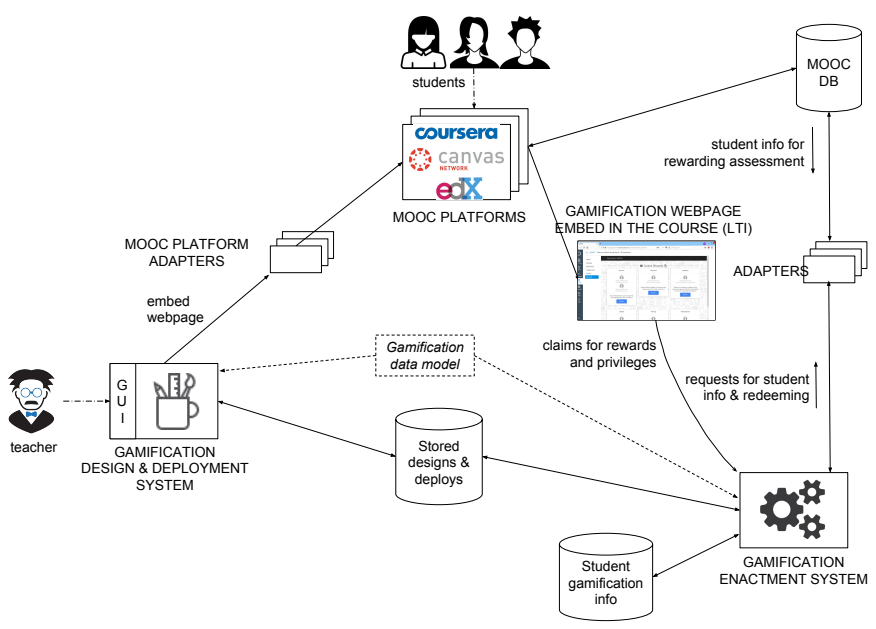

Fig. 2. Proposed architecture for designing, implementing and enacting incourse redeemable rewards in MOOCs.

\section{SCEnARio}

In this section we describe a simple scenario to illustrate the usage of the proposed gamification approach and the envisioned systems supporting teachers in the gamification design, deployment and enactment, from both the teachers' and students' perspectives.

\section{A. Teachers' Perspective}

Christian and Ana (C\&A) are two teachers from the School of History at the University of Valencia (Spain) who will offer a MOOC about history of Spain during the XI-XVI century period. After a meeting with the vice-rector of the university, they agreed to launch the course in the official MOOC platform at University of Valencia (i.e, Canvas Network ${ }^{4}$ ), estimating more than 1000 enrolled participants. C\&A will reuse some pedagogical contents and resources (e.g., readings to discuss, questionnaires, activities with Google Earth) frequently used in their bachelor courses, and restructure them for this MOOC. Moreover, C\&A have recorded some videos embedding digital graphics to help students better understand the simultaneous happenings during a time period. Therefore, the pedagogical design of the course is structured in 6 modules (one century per module) provided in 6 weeks (a new module is open every week) involving content pages, forums and activities with different tools as it is shown in Fig. 3.

C\&A will incorporate in-course redeemable rewards in order to keep students engaged within the course. To do so, C\&A make use of the envisioned tool for designing and deploying gamification (see Fig. 4). The tool also allows to configure the relationships among the students' rewardable actions performed in the different tools (e.g., post in a forum), the conditions the actions must met (e.g., receive 25 likes), and the redeemable rewards (e.g., become teacher assistant of such forum), and automatically deploy gamification designs created

\footnotetext{
${ }^{4}$ Canvas Network. Available at $h t t p s: / / w w w . c a n v a s . n e t /$, last access: November, 2017.
}

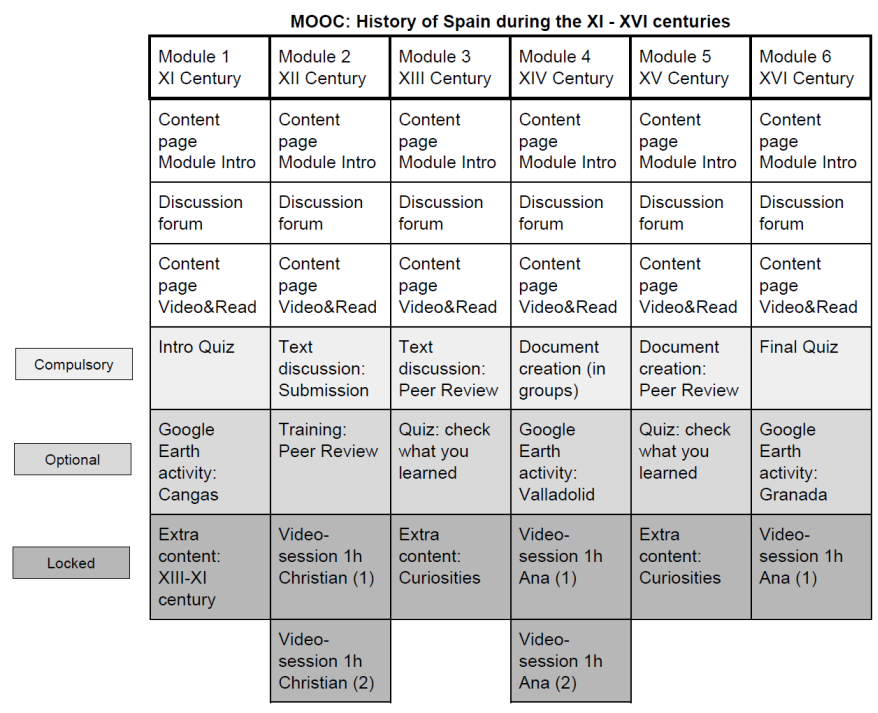

Fig. 3. MOOC design including the compulsory, optional and locked activities.

by teachers into MOOC courses (in this case, into courses in Canvas Network platform).

Following the steps and recommendations of the tool, C\&A created and configured a gamification design with in-course rewards based on their criteria by associating the activities, the monitorable students' actions and the actions' conditions. After less than an hour, the final gamification design is configured by C\&A as shown in Fig. 5. For example, students can claim a ticket to be redeemed for:

- Getting a teacher assessment (in addition to peer assessments) in "Peer Review activity @ Module 3" when scoring more than 90\% in the "Intro Quiz @ Module 1 ".

- Becoming teacher assistant of the course when receiving 20 or more likes among all the comments posted in the discussion forums of the course.

- Getting access to an exclusive on-live video session with one of the teachers @ Module 5 when submitting an extra review apart from the compulsory ones in "Peer Review activity @ Module 3".

Finally, such gamification design is automatically deployed into the history of Spain MOOC when C\&A press the button for deploying the configured gamification design, i.e., students can see a gamification tab with the configured rewards, their criteria to earn them, and one button to request them (see Fig. 6).

During the enactment of the MOOC, C\&A are in charge of managing the course as it happens in most MOOCs (e.g., checking the contents, answering questions in forums, preparing the video sessions) without adding extra time and effort for the gamification features (except those rewards that imply teacher involvement). Also, the envisioned gamification system should be able to:

- Receive the students' requests for earning and redeeming the configured rewards, and automatically, check if the 


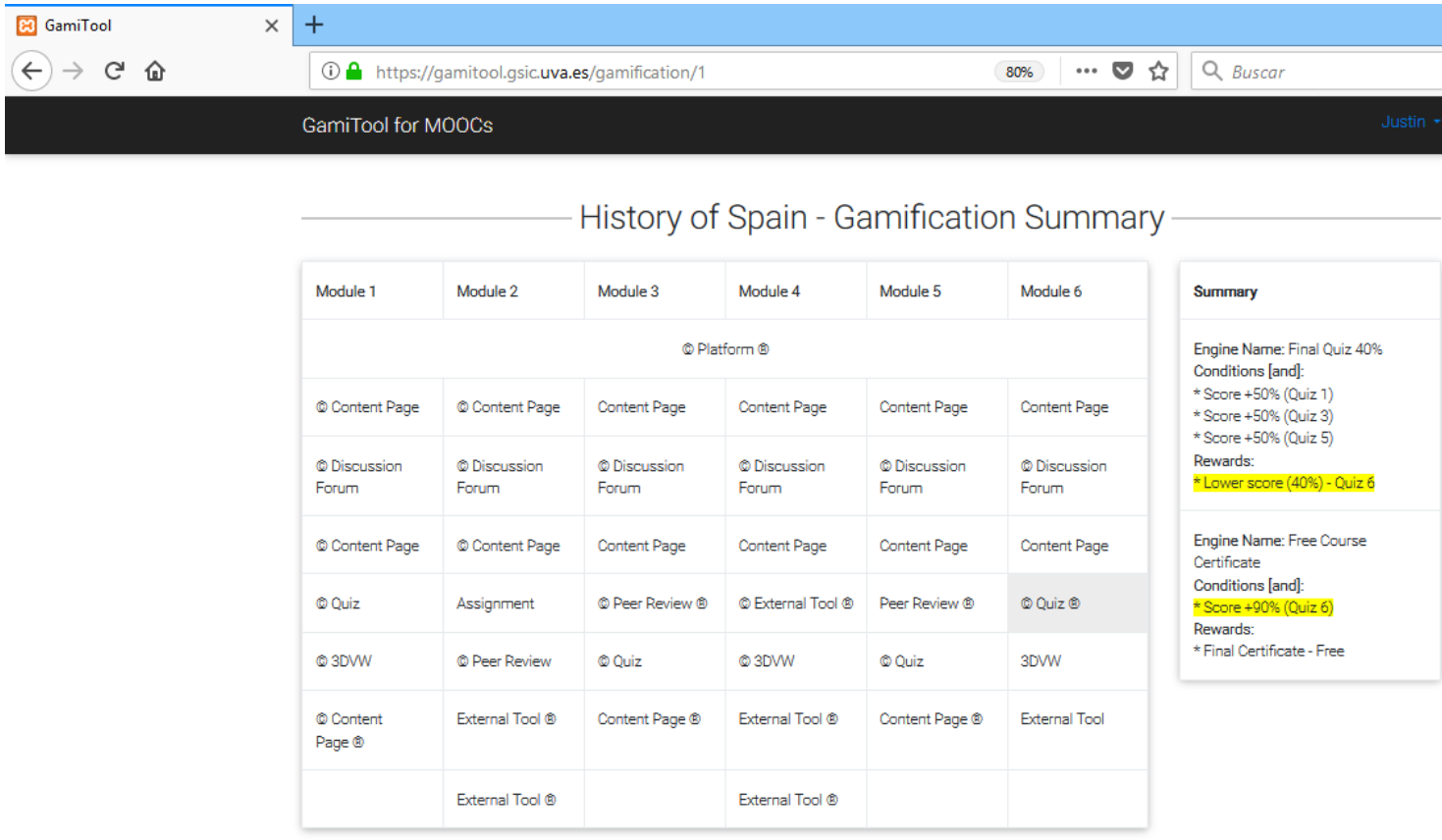

- History of Spain - Gamification Associations

Fig. 4. Graphical user interface of the envisioned tool for designing and implementing in-course redeemable rewards. (C) and $(\mathbb{R})$ characters indicate that the resource has an associated gamification condition and reward respectively.

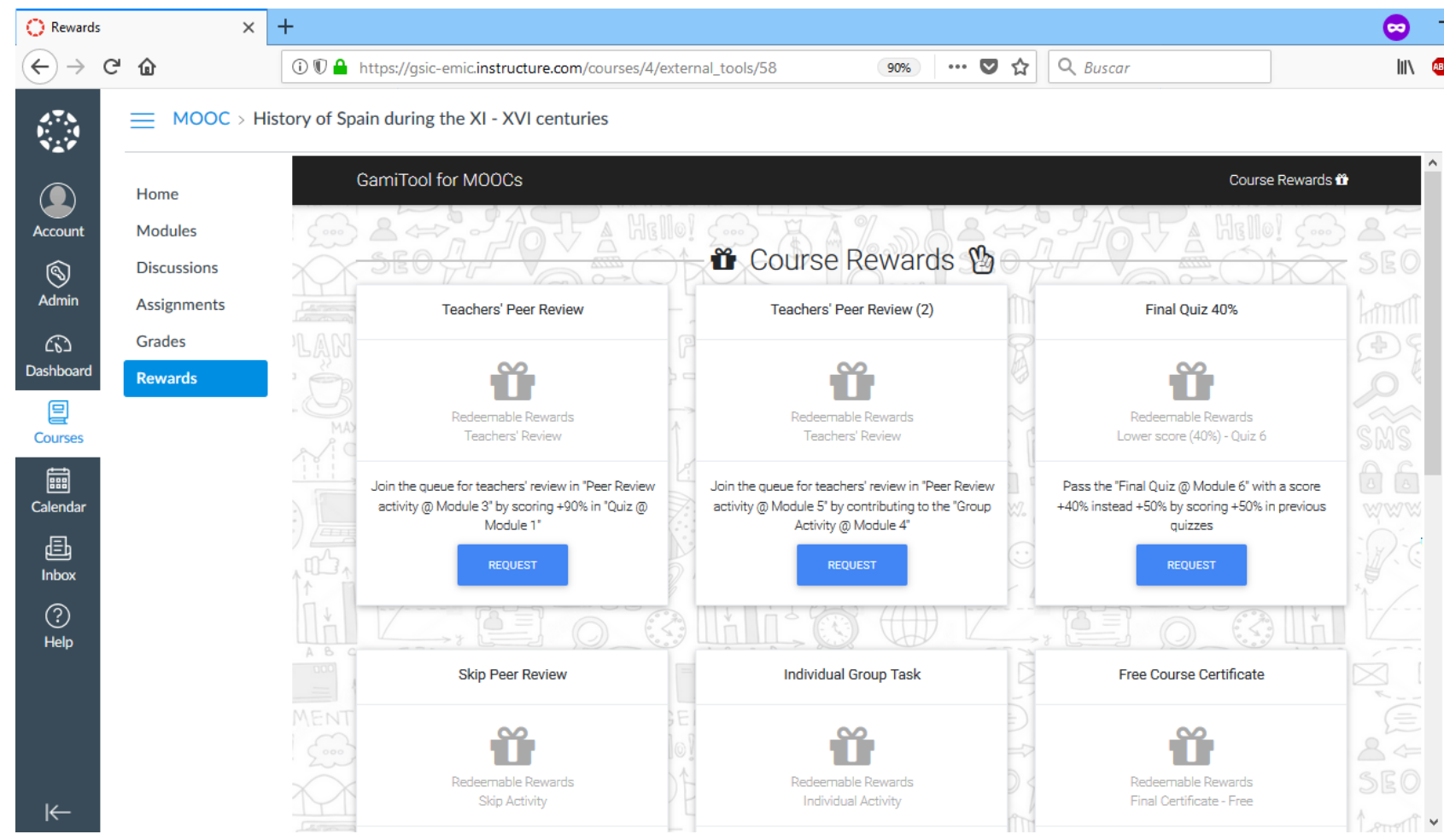

Fig. 6. Redeemable rewards design that is described in the given MOOC teaching scenario (students' view). 


\begin{tabular}{|c|c|c|c|}
\hline $\begin{array}{l}\text { Rewards: } \\
\text { Tickets }\end{array}$ & Tools / Activities & Conditions & $\begin{array}{l}\text { Redeemable } \\
\text { Privileges }\end{array}$ \\
\hline 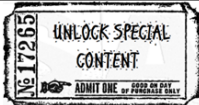 & Course platform & $\begin{array}{l}\text { Upload a profile } \\
\text { picture }\end{array}$ & $\begin{array}{l}\text { Unlockspecial } \\
\text { content: } \\
\text { "Extra Content @ } \\
\text { Module 1" }\end{array}$ \\
\hline 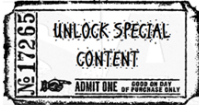 & $\begin{array}{l}\text { Google Earth activity: } \\
\text { Cangas@ Module } 1\end{array}$ & $\begin{array}{l}\text { Interact with all (5) } \\
\text { the artifacts }\end{array}$ & $\begin{array}{l}\text { Unlockspecial } \\
\text { content: } \\
\text { "Extra Content @ } \\
\text { Module 3" }\end{array}$ \\
\hline 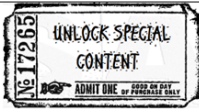 & $\begin{array}{l}\text { Google Earth activity: } \\
\text { Valladolid @ Module } 4\end{array}$ & $\begin{array}{l}\text { Interact with all (5) } \\
\text { the artifacts }\end{array}$ & $\begin{array}{l}\text { Unlockspecial } \\
\text { content: } \\
\text { "Extra Content @ } \\
\text { Module 5" }\end{array}$ \\
\hline (2) ECLUSNE & Course platform & $\begin{array}{l}\text { Visit all content } \\
\text { pages from } \\
\text { Modules } 1 \text { \& } 2\end{array}$ & $\begin{array}{l}\text { Access to an } \\
\text { exclusive video- } \\
\text { session (Module 2) }\end{array}$ \\
\hline 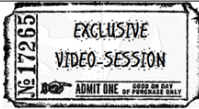 & $\begin{array}{l}\text { Text discussion: Peer } \\
\text { Review1@ Module } 3\end{array}$ & $\begin{array}{l}\text { Review one extra } \\
\text { submission from a } \\
\text { peer }\end{array}$ & $\begin{array}{l}\text { Access to an } \\
\text { exclusive video- } \\
\text { session (Module 5) }\end{array}$ \\
\hline 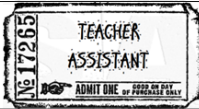 & $\begin{array}{l}\text { Discussion forums of } \\
\text { the course }\end{array}$ & $\begin{array}{l}\text { Receive } 20+\text { likes in } \\
\text { forums }\end{array}$ & $\begin{array}{l}\text { Become teacher } \\
\text { assistant of the } \\
\text { course }\end{array}$ \\
\hline 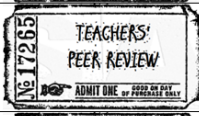 & Intro Quiz@ Module 1 & Score $>90 \%$ & $\begin{array}{l}\text { Join the queue for } \\
\text { teachers' review in } \\
\text { "Peer Reviewactivity } \\
\text { @ Module 3" }\end{array}$ \\
\hline PEAGHERS & $\begin{array}{l}\text { Group activity: Google } \\
\text { document @ Module } \\
4\end{array}$ & $\begin{array}{l}4 \text { out of } 5 \\
\text { members of the } \\
\text { group contribute } \\
\text { to the document }\end{array}$ & $\begin{array}{l}\text { Join the queue for } \\
\text { teachers' review in } \\
\text { "Peer Review activity } \\
\text { @Module 5" }\end{array}$ \\
\hline 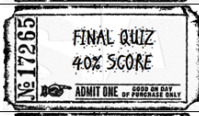 & $\begin{array}{l}\text { Intro Quiz @ Module } 1 \\
\text { Quiz@ Module } 3 \\
\text { Quiz @ Module 5 }\end{array}$ & Score $>50 \%$ & $\begin{array}{l}\text { Pass the "Final Quiz } \\
@ \text { Module 6" with a } \\
\text { score }>40 \% \text { instead } \\
\text { of }>50 \%\end{array}$ \\
\hline 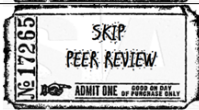 & $\begin{array}{l}\text { Peer Review activity @ } \\
\text { Module } 3\end{array}$ & $\begin{array}{l}\text { Review } 5+ \\
\text { submissions and } \\
10+\text { comments per } \\
\text { submission }\end{array}$ & $\begin{array}{l}\text { Skip the "Peer } \\
\text { Review activity @ } \\
\text { Module 5" }\end{array}$ \\
\hline 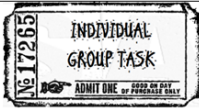 & $\begin{array}{l}\text { Training Peer Review } \\
@ \text { Module } 2\end{array}$ & $\begin{array}{l}\text { Score the example } \\
\text { with a validity<0.1 } \\
\text { (score similaras } \\
\text { teacher'sscore) }\end{array}$ & $\begin{array}{l}\text { Perform the "Group } \\
\text { Activity @ Module 4" } \\
\text { individually }\end{array}$ \\
\hline 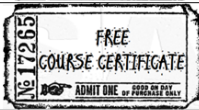 & Final Quiz@ Module6 & $\begin{array}{l}\text { Score }>90 \% \& \\
\text { Submit all the } \\
\text { compulsory and } \\
\text { optional tasks }\end{array}$ & $\begin{array}{l}\text { Get the final } \\
\text { certificate of the } \\
\text { course without fee }\end{array}$ \\
\hline
\end{tabular}

Fig. 5. Summary of the designed and configured in-course redeemable rewards in the scenario.

requirements have been meet (i.e., retrieving the needed information from the platform API to know whether such student has performed the pre-defined associated conditions) and if so, reward the student.

- Receive the students' requests to redeem rewards and provide students with the associated privileges (e.g., using the API to change the role of a participant from "student" to "teacher assistant").

- Provide awareness information to the teachers about the progress and number of redeems for each privilege. This information may serve the teachers to various ends: to implement the redeemable rewards that they have to carry out manually (e.g., assess a students' output), to monitor the evolution of the rewards, which may help to re-design the course in the current or following editions, etc.

\section{B. Students' Perspective}

David is a mechanical engineering master student who loves history. One day, David finds an ad about a history of Spain MOOC that draws his attention. Although David is not interested in getting the final certificate, he decided to join this MOOC to spend his free time learning what he likes. Although David's initial motivation and engagement is high, his motivation could decrease during the next weeks due to David's lack of free time and compulsory and time-consuming assignments.

After taking a look to the configured in-course redeemable rewards (see Fig. 6), he is surprised by the extra contents and the on-live video sessions with the teachers to discuss with them the learning material. David is engaged with the course and quite interested on getting such rewards and intrinsically motivated to complete the reward requirements. Trying to get such privileges, he uploads a profile picture, completes the Google Earth activities, reviews the assigned peer-review submissions and performs an extra review, during the first two modules of the course (see Fig. 5). As a consequence, David gets rewards that can be redeemed for getting access to special activities and pages (i.e., video-sessions with teachers, extra contents) in the 2-5 modules of the course. Therefore, although David loses the interest in the regular content pages on these modules, he is still motivated to participate in such video-sessions and download the extra contents.

In this situation, David has participated in activities of modules 1-2 in order to get the rewards, and in activities in modules 2-5 in order to use such rewards, keeping his high engagement levels though the different modules and weeks of the course. In case that teachers omitted this gamification strategy, or implemented a gamification strategy with status badges, David would not have participated in the Google Earth activities and the peer reviews in modules 1-2, and maybe his motivation level would have decreased enough in modules 3-4 to stop the course.

\section{CONClusion And Future Work}

Gamification strategies have shown potential benefits, not only in student motivation and engagement but also in promoting participation and improving learning, in different educational environments. As a consequence, there is an increasing number of studies using gamification techniques to help overcome some of the aforementioned MOOC problems [18]. This paper has identified in-course redeemable rewards in educational contexts as potential game elements to increase student engagement in educational settings. Although some MOOC features can hinder the application of gamification strategies (e.g., the large number of students, the variety of students' profiles, the pedagogical approach), these features also provide teachers with opportunities to positively use redeemable rewards (e.g., the large number of students allows to provide teachers' individual attention as rewards, the flexibility in MOOC designs caused by the pedagogical approach allows to provide special resources and activities as rewards).

We have discussed in this paper the general concept of redeemable rewards, how they are associated with other rewarding-based gamification elements, a set of systems supporting its implementation and a scenario supporting teachers in the design, deployment and enactment of in-course 
redeemable rewards. Such systems should provide teachers with hints on how to better gamify and associate the learning activities with the course privileges to increase student motivation, and allow the automatic deployment and enactment of the configured gamifications to make their implementation affordable for teachers in terms of time and effort.

The scenario showed a simple gamification approach where a traditional reward (i.e., tickets) were associated to different course privileges. More complex situations involving more rewards and/or shops where students can exchange the rewards should be considered for the development of future tools. Also, it is important to mention that these systems are limited by the capabilities of the MOOC platforms to retrieve and edit information from and to the databases. Therefore, MOOC platforms with a limited access to their databases hinder the automation of redeemable rewards, and thus their implementation.

Our future work will focus on involving teachers as codesigners of the described rewarding system in MOOCs to validate which activities and rewards should be connected. In addition, we are building a working prototype of the system (integrating the proposed gamification data model and architecture) to refine the proposal with real users and empirically measure effects on student motivation. Furthermore, it would be also interesting to check the benefits of using learningoriented out-course rewards such as free enrollments to other courses (e.g., second versions of the courses), providing privileges to other courses (e.g., being teacher assistant of another course), or gifting game or useful software.

\section{ACKNOWLEDGMENTS}

This research has been partially funded by the Spanish Ministry of Economy and Competitiveness, under project grants TIN2014-53199-C3-2-R and TIN2017-85179-C3-2-R, and the Regional Goverment of Castilla y León together with the European Regional Development Fund, under project grant VA082U16. The authors thank the rest of the GSIC-EMIC research team for their valuable ideas and support.

\section{REFERENCES}

[1] Carlos Alario-Hoyos, Mar Pérez-Sanagustín, Carlos Delgado-Kloos, Hugo A. Parada G., and Mario Muñoz-Organero. Delving into Participants' Profiles and Use of Social Tools in MOOCs. IEEE Transactions on Learning Technologies, 3(7):260-266, 2014.

[2] Alessandra Antonaci, Roland Klemke, Christian M Stracke, and Marcus Specht. Gamification in MOOCs to enhance users' goal achievement. In Proceedings of the 2017 Global Engineering Education Conference (EDUCON), pages 1654-1662. IEEE, 2017.

[3] Richard Bartle. Hearts, clubs, diamonds, spades: Players who suit muds. Journal of MUD research, 1(1):19, 1996.

[4] Christopher P Cerasoli, Jessica M Nicklin, and Michael T Ford. Intrinsic motivation and extrinsic incentives jointly predict performance: A 40year meta-analysis. Psychological bulletin, 140(4):980, 2014.

[5] Jen-Wei Chang and Hung-Yu Wei. Exploring Engaging Gamification Mechanics in Massive Online Open courses. Journal of Educational Technology \& Society, 19(2):177-203, 2016.

[6] S. De Sousa Borges, V.H.S. Durelli, H.M. Reis, and S. Isotani. A systematic mapping on gamification applied to education. In Proceedings of the 29th Annual ACM Symposium on Applied Computing, pages 216222. ACM, 2014
[7] Sebastian Deterding, Dan Dixon, Rilla Khaled, and Lennart Nacke. From Game Design Elements to Gamefulness: Defining Gamification. In Proceedings of the 15th ACM International Academic MindTrek Conference: Envisioning Future Media Environments, pages 9-15, 2011.

[8] Darina Dicheva, Christo Dichev, Gennady Agre, and Galia Angelova. Gamification in education: a systematic mapping study. Journal of Educational Technology \& Society, 18(3):75-88, 2015.

[9] Darina Dicheva, Keith Irwin, Christo Dichev, and Swapna Talasila. A course gamification platform supporting student motivation and engagement. In Proceedings of the 2014 International Conference on Web and Open Access to Learning (ICWOAL), pages 1-4. IEEE, 2014.

[10] Lu Ding, ChanMin Kim, and Michael Orey. Studies of student engagement in gamified online discussions. Computers \& Education, $115: 126-142,2017$

[11] Juho Hamari. Do badges increase user activity? A field experiment on the effects of gamification. Computers in human behavior, 71:469-478, 2017.

[12] Katy Jordan. Initial trends in enrolment and completion of massive open online courses. The International Review of Research in Open and Distributed Learning, 15(1):133-160, 2014.

[13] Hanan Khalil and Martin Ebner. MOOCs completion rates and possible methods to improve retention-A literature review. In Proceedings of the World Conference on Educational Multimedia, Hypermedia and Telecommunications, pages 1305-1313, 2014.

[14] Anoush Margaryan, Manuela Bianco, and Allison Littlejohn. Instructional quality of massive open online courses (MOOCs). Computers \& Education, 80:77-83, 2015.

[15] Miguel Morales, Hector R Amado-Salvatierra, Rocael Hernández, Johanna Pirker, and Christian Gütl. A Practical Experience on the Use of Gamification in MOOC Courses as a Strategy to Increase Motivation. In Proceeding of the International Workshop on Learning Technology for Education in Cloud, pages 139-149. Springer, 2016.

[16] Siobhan O'Donovan, James Gain, and Patrick Marais. A case study in the gamification of a university-level games development course. In Proceedings of the South African Institute for Computer Scientists and Information Technologists Conference, pages 242-251. ACM, 2013.

[17] Alejandro Ortega-Arranz, Alejandra Martínez-Monés, Erkan Er, Miguel L. Bote-Lorenzo, Juan I. Asensio-Pérez, and Juan A. MuñozCristóbal. Analyzing Students' Intentions to Earn Badges in a MOOC. International Journal of Human-Computer Studies (submitted), 2018.

[18] Alejandro Ortega-Arranz, Juan A. Muñoz-Cristóbal, Alejandra Martínez-Monés, Miguel L. Bote-Lorenzo, and Juan I. Asensio-Pérez. How Gamification is Being Implemented in MOOCs? A Systematic Literature Review. In Proceedings of the Twelfth European Conference on Technology Enhanced Learning, pages 441-447. Springer, 2017.

[19] R.H. Rizzardini, M.M. Chan, and Guetl C. An Attrition Model for MOOCs: Evaluating the Learning Strategies of Gamification. Formative Assessment, Learning Data Analytics and Gamification: In ICT Education. Elsevier, 2016.

[20] Robab Saadatdoost, Alex Tze Hiang Sim, Hosein Jafarkarimi, and Jee Mei Hee. Exploring MOOC from education and Information Systems perspectives: A short literature review. Educational Review, 67(4):505518, 2015.

[21] D. Shah. Monetization over Massiveness: A Review of MOOC stats and Trends in 2016. Retrieved from: https://www.classcentral.com/report/moocs-stats-and-trends-2016/ last access: April 2017, 2016.

[22] Jorge Simões, Rebeca Díaz Redondo, and Ana Fernández Vilas. A social gamification framework for a K-6 learning platform. Computers in Human Behavior, 29(2):345-353, 2013.

[23] Ralf Teusner, Kai-Adrian Rollmann, and Jan Renz. Taking Informed Action on Student Activity in MOOCs. In Proceedings of the Fourth (2017) ACM Conference on Learning@ Scale, pages 149-152. ACM, 2017.

[24] Xiaoji Xu and Huanyu Zhi. Study Of Game Elements Impacting On SE Course Completion Rate In MOOCs. Master's thesis, Faculty of Computing, Blekinge Institute of Technology, SE-371 79, Karlskrona, Sweden, 2017.

[25] Gabe Zichermann and Christopher Cunningham. Gamification by design: Implementing game mechanics in web and mobile apps. O'Reilly Media, Inc., 2011. 